\title{
DESAIN USER INTERFACE GAME FAIRPLAY POKER MENGGUNAKAN METODE UCD (USER CENTERED DESIGN)
}

\author{
Henry Bastian ${ }^{1}$, Godham Eko Saputro ${ }^{2}$ \\ ${ }^{12}$ Desain Komunikasi Visual, Universitas Dian Nuswantoro Semarang \\ hnrbast@gmail.com ${ }^{1}$, godham.eko@gmail.com²
}

\begin{abstract}
Abstrak
Di Indonesia, salah satu permainan yang menjadi kegemaran adalah bermain game Poker. Poker merupakan permainan kartu aturan yang dapat dimainkan secara langsung maupun lewat internet. Game Poker online adalah salah satu sarana efektif untuk menghabiskan waktu sekaligus hiburan kesenangan bermain poker dengan banyak orang. Salah satu game Poker yang terkenal adalah Zynga Poker. Pencarian data yang ditemukan bahwasannya permainan tersebut mempunyai kekurangan pada bagian user interface yang berat saat digunakan sehingga penulis mencoba untuk membuat user interface game online sejenis menggunakan metode UCD (UserCentered Design) dengan nama game FairPlay Poker. Desain yang dihasilkan adalah desain ilustrasi 2D yang digunakan dengan lebih ringan.
\end{abstract}

Kata kunci: Game, metode UCD, User interface, Poker,

\begin{abstract}
In Indonesia, one of the favorite online games is poker. Poker is a card game with some rules that can be played directly or via the internet. Online Poker game is one of the effective media to spend time and amuse pleasure by playing poker with peoples. The Infamous Poker game is known as Zynga Poker. From the data search that had been done, the game still has a few weaknesses in the heavy User Interface that the authors try to develop a similar user interface poker game. Which name the Fairplay Poker using UCD (User-Centered Design) methodology. A design resulted in an illustration designed in 2D that can improve loading with lighter.
\end{abstract}

Keywords: Game, UCD Method, User interface, Fairplay 


\section{PENDAHULUAN}

Aktivitas berselancar di dunia maya sepertinya sudah bukan merupakan hal asing bagi kebanyakan orang. Mulai dari chatting, aktif di media sosial, hingga bermain game online banyak diminati oleh semua kalangan dan usia. Di dunia maya banyak ditemukan game online dengan berbagai tema seperti balap, perang, simulasi, dan poker. Gamegame tersebut yang dimainkan oleh banyak penikmat game di Indonesia. Game Poker merupakan permainan kartu aturan yang dapat dimainkan secara langsung maupun lewat internet. Game Poker online adalah salah satu sarana efektif untuk menghabiskan waktu sekaligus hiburan bermain poker dengan banyak orang. Reward yang ditawarkan oleh game ini adalah menguji kemampuan melawan para master poker di seluruh dunia dan menjadi dewa judi terhebat di dunia maya. Salah satu tempat bermain game poker online bagi penikmat game ini adalah situs Itupoker.com. Sebuah agen poker online Indonesia terpercaya yang banyak menelurkan reward berupa bonus jackpot jutaan rupiah.

Zynga poker dan Texas Hold'em Poker merupakan contoh kecil dimana permainan poker yang dibuat versi game dalam berbagai platform dan menjadi populer. Texas Hold'em Poker adalah salah satu game poker online yang dapat dimainkan di jejaring sosial Facebook, dan menduduki peringkat teratas dari sepuluh game yang paling banyak dimainkan di Indonesia pada Juni 2013 menurut lembaga analisis MetricsMonk (Deliusno, 2013). Sedangkan Zynga poker menjadi game aplikasi yang telah diunduh lebih dari 50 juta kali pada laman google play. Dari banyaknya feedback yang memberikan nilai positif (bintang 5) untuk aplikasi zynga, pulis juga menemukan bahwasannya terdapat pula feedback yang memberikan nilai negatif (bintang 1 atau 2). Feedback negatif sebagian besar mempermasalahkan terlalu beratnya aplikasi untuk dijalankan karena tampilan yang kompleks serta banyaknya iklan yang bertaburan pada aplikasi game. Hal ini karena pengguna menilai suatu sistem hanya dengan melihat tampilan luarnya atau user interface sehingga perancangan user interface perlu dipikirkan secara mendalam sehingga dapat menghasilkan interface yang efektif (Suteja \& Harjoko, 2008) dengan berfokus pada desain user interface.

User interface adalah wilayah tempat terjadinya interaksi antara program dan pengguna, yang memungkinkan sistem menerima input (masukan informasi) dari pengguna sehingga muncul output (luaran) dari sistem (Mcleod, 1995). Sehingga dapat dikatakan pula bahwa user interface juga merupakan sistem yang digunakan pengguna untuk berinteraksi dengan objek rancangan, sehingga tidak hanya berwujud visual namun juga dapat berwujud suara (Olga, 2015).

Sama halnya dengan Mcleod, Sani (2014) juga berpendapat bahwa user interface (UI) merupakan bagian dari sistem informasi yang membutuhkan interaksi pengguna untuk membuat inputs dan outputs. User interface meliputi a) aspek fisik, merupakan aspek yang berkaitan dengan perangkat keras yang digunakan oleh pengguna seperti layar sentuh mouse ataupun keyboard; b) aspek perseptual,merupakan aspek yang berkaitan dengan panca indra pengguna seperti segala sesuatu yang dapat dilihat, dirasakan dan didengar pengguna; c) Aspek konseptual, merupakan aspek yang berkaitan dengan tata 
cara penggunaan seperti contoh prosedur yang harus diikuti saat menjalankan sebuah sistem. (Sani, 2014)

Dalam penelitian ini penulis mencoba untuk membuat user interface game poker online sejenis dengan nama FairPlay Poker dengan menggunakan metode UCD (User Centered Design). FairPlay Poker dibuat untuk dapat digunakan dengan lebih ringan namun tetap dirancang semenarik mungkin sehingga mudah digunakan saat dimainkan. User interface sendiri adalah tampilan luar atau visual desain dari sebuah aplikasi yang dapat dilihat secara kasat mata dan mencakup didalamnya adalah layout.

\section{METODE PENELITIAN}

Dalam penelitian ini penulis menggunakan metode kualitatif dengan alat analisis UCD (User Centered Design) (Abras, et al., 2004) dalam mengembangkan desain User interface karena memiliki fokus pada kebutuhan dan pengalaman pengguna.

Dalam UCD beberapa prinsip seperti pentingnya memahami pengguna secara jelas, desain dibuat berdasarkan evaluasi dan pengalaman pengguna serta keikutsertaan klien dalam merancang desain. Dalam prosesnya UCD dibagi menjadi 4 tahapan seperti terlihat pada gambar 1

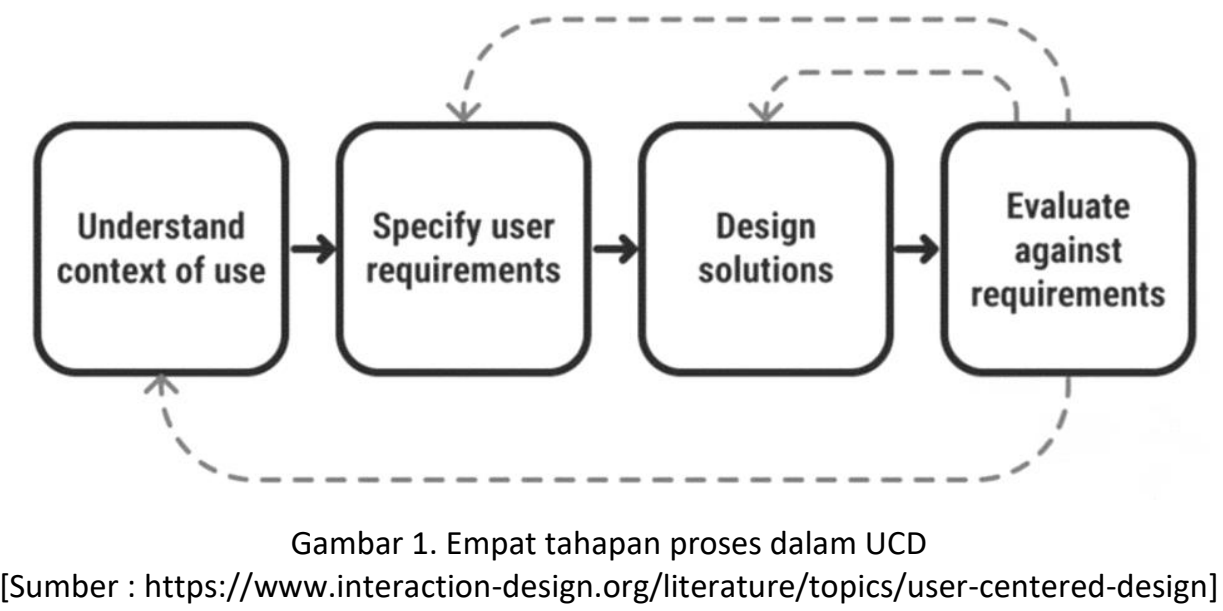

Tahap 1 yaitu Understand Context of Use; memahami konteks dari penggunaan, disini perancang yaitu penulis perlu paham sikap pengguna dengan mengumpulkan data yang berkaitan dengan pengguna. Tahap 2 yaitu Specify User Requirements; menspesifikasikan kebutuhan pengguna, kebutuhan pengguna dapat dilihat dari tujuan yang hendak dicapai oleh pengguna. Tahap 3 yaitu Design Solutions; Solusi desain didapat melalui beberapa tahapan mulai dari pembuatan konsep, pembuatan prototype dan terakhir pembuatan desain akhir. Tahap 4 yaitu Evaluation Against Requirements; Evaluasi akan dilakukan dengan melibatkan pengembang yang akan menggunakan, evaluasi dilakukan mulai dari 1 proses dan dilanjutkan ke proses berikutnya. 


\section{HASIL DAN PEMBAHASAN}

Proses perancangan dimulai dari User interface Wireframe sebagai landasan perancangan desain. Wireframe digunakan sebagai acuan dasar layout dari desain game yang akan dirancang.

Tahap I Understand Context of Use

Dari hasil observasi yang dilakukan penulis pada salah satu game poker, diketahui bahwasannya user interface yang digunakan masih tampak membingungkan, hal ini diketahui dari beberapa poin yaitu:

a. User interface terlihat berat sehingga terkadang perlu beberapa saat untuk menampilkan keseluruhan desain interface.

b. Tidak adanya area dalam meminta bantuan atau area pengguna dapat menemukan informasi mengenai game.

c. Tidak adanya keterangan pada beberapa bagian seperti informasi tentang league.

\section{Tahap 2 Specify User Requirements}

Berdasarkan Informasi yang didapat, penulis menspesifikasikan kebutuhan pengguna pada desain yang tidak menghasilkan file yang berat. Hal tersebut bisa didapat dari penggunaan desain yang clean dan simple, ilustrasi yang tidak terlalu komplek dalam pewarnaannya. Adapun game play yang akan digunakan akan lebih sederhana dan minimalis yaitu

1. Pemain masuk kedalam opening board

2. Setelah itu login board akan muncul. Bagi pengguna yang telah memiliki akun, pengguna dapat langsung masuk melalui laman ini namun jika belum pengguna baru perlu melakukan registrasi.

3. Pengguna baru yang melakukan registrasi akan diminta mengisi informasi tentang pengguna

4. Pengguna dapat masuk ke home board setelah login baru kemudian dapat masuk kedalam.

5. Bila terdapat hal-hal yang tdk diketahui pengguna juga dapat membuka halaman informasi mengenai game.

6. Kemudian setelah masuk kedalam main board pengguna dapat memilih 3 permainan yang ada yaitu casual game, kompetisi game dan Fun Game.

\section{Tahap 3 Design solution}

Proses perancangan dimulai dari pembuatan user interface wireframe sebagai landasan pembuatan desain. Wireframe digunakan sebagai acuan dasar layout dari desain game yang akan dibuat. 
Tabel 1. Tahap desain dalam user interface wireframe

[Sumber: Henry Bastian, 2020]

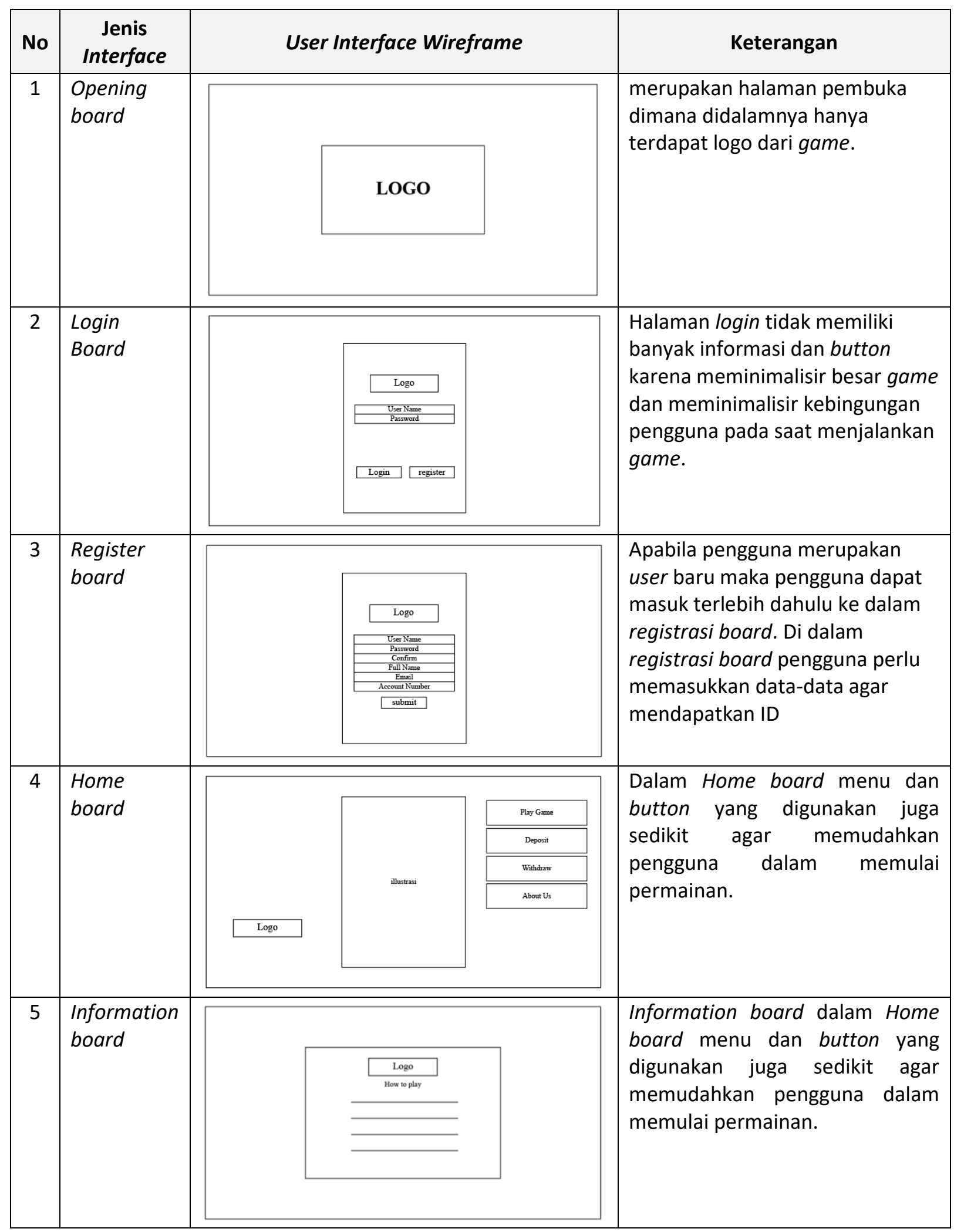




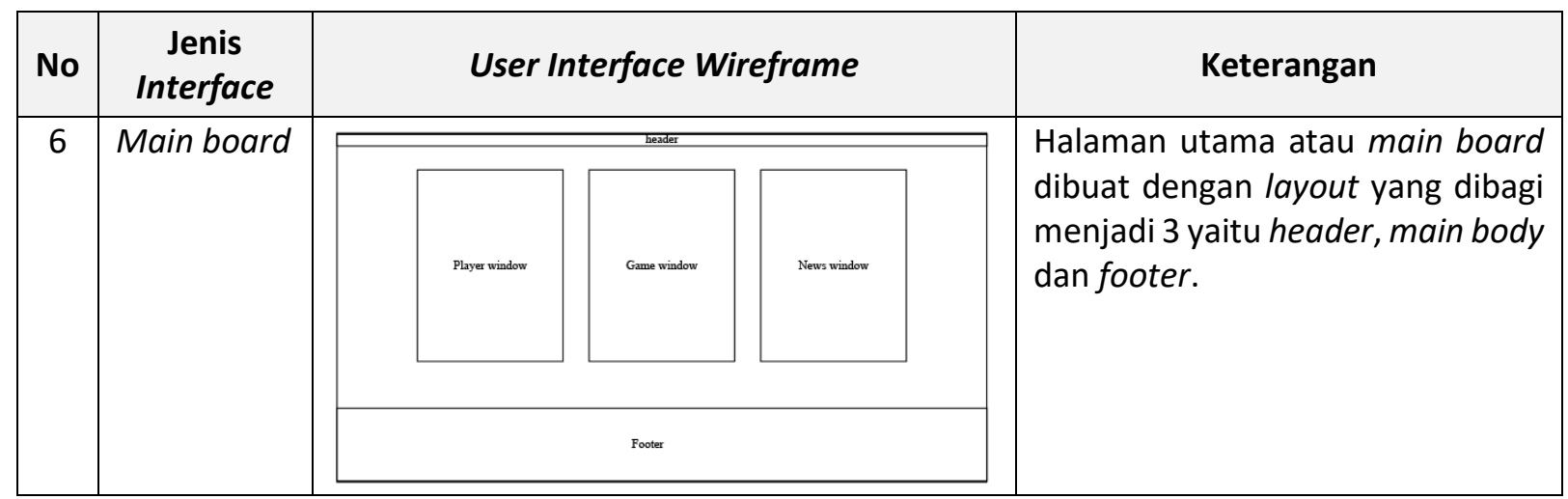

4. Desain User Interface

Setelah melakukan cognitive walktrough langkah selanjutnya yang dilakukan penulis adalah mengimplementasikan ide yang berasal dari feedback pengguna dan pihak pengembang untuk perancangan desain grafis secara visual.

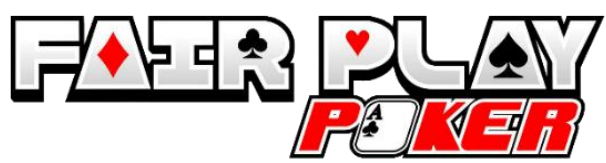

Gambar 2. Logo game Fairplay

[Sumber: Henry Bastian, 2020]

Gambar 2 merupakan logo dari Fair Play Poker sebagai identitas dari game. Logo akan banyak digunakan adalah halaman game selain sebagai identitas namun juga sebagai pengingat agar pengguna mengingat dan mengenali identitas game. Warna utama yang digunakan dalam game adalah hijau, merah, hitam dan putih. Warna merah, hitam dan putih dipilih pertama kali berdasarkan warna yang ada pada kartu kemudian, warna hijau muncul dari warna komplementer merah sehingga warna benar benar kontras (gambar 3).

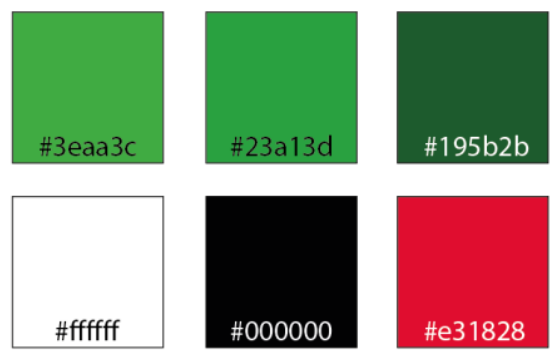

Gambar 3. Code warna yang digunakan dalam game

[Sumber: Henry Bastian, 2020]

Adapun dalam penggunaan huruf Fairplay menggunakan typeface dengan serif yang sederhana dan tidak terkesan penuh sehingga tingkat keterbacaan menjadi lebih tinggi. Beberapa ilustrasi juga dibuat untuk memaksimalkan desain UI yang ada, namun desaindesain yang dibuat tetap menggunakan ilustrasi 2D yang memungkinkan hasil desain tidak berat. Adapun ilustrasi tambahan digunakan pada bagian latar game, latar board dan ilustrasi perempuan sebagai ilustrasi yang dapat menarik perhatian pengguna. 
Berikut desain dari beberapa board yang akan digunakan dalam game Fairplay Poker

Tabel 2. Desain User Interface game Fairplay Poker

[Sumber: Henry Bastian, 2020]

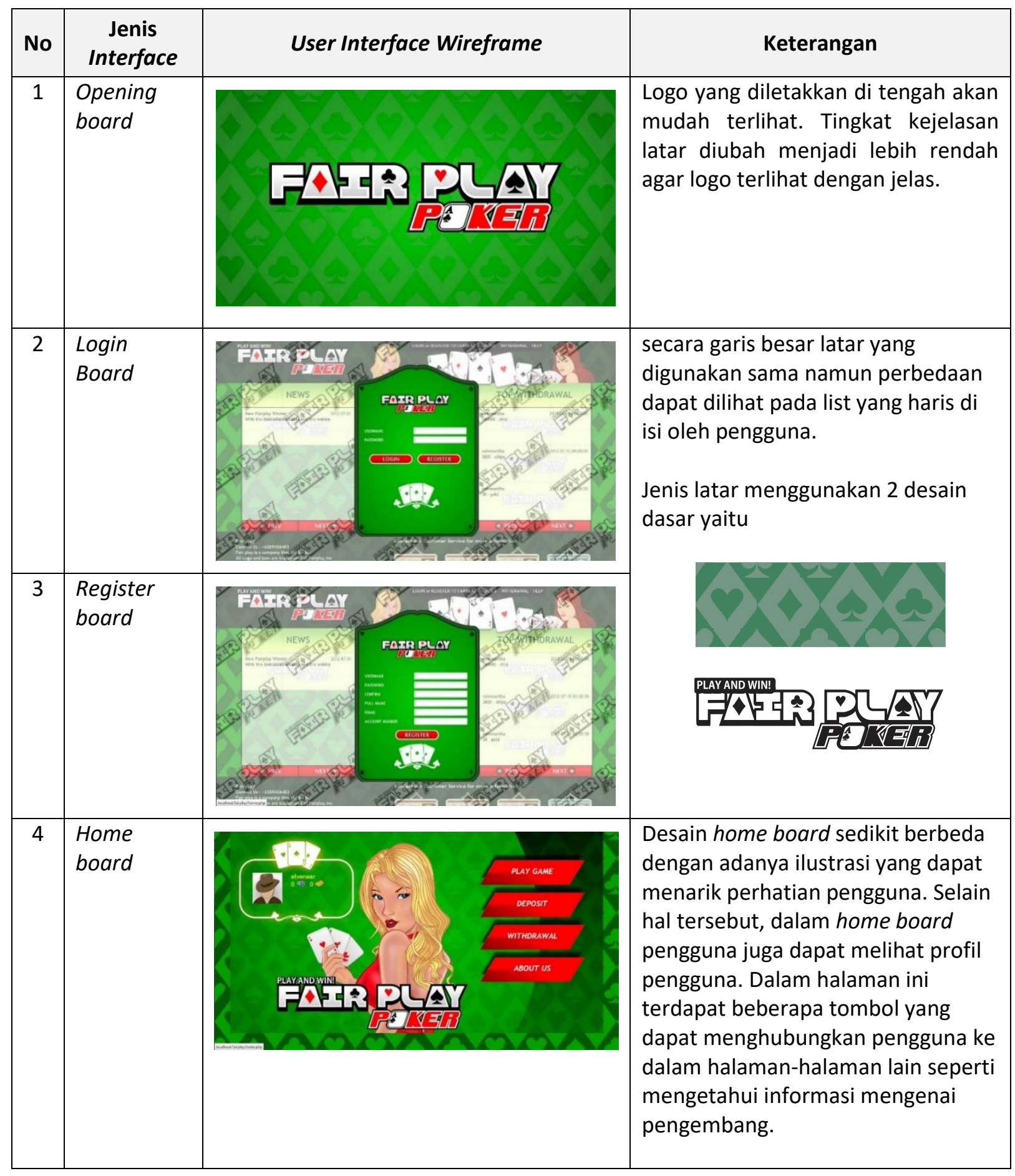




\begin{tabular}{|c|c|c|c|}
\hline No & $\begin{array}{c}\text { Jenis } \\
\text { Interface }\end{array}$ & User Interface Wireframe & Keterangan \\
\hline 5 & $\begin{array}{l}\text { Information } \\
\text { board }\end{array}$ & & $\begin{array}{l}\text { desain latar board dibuat } \\
\text { menyerupai desain board pada login } \\
\text { dan registrasi board sebagai } \\
\text { konstanta desain namun variabel } \\
\text { yang digunakan adalah dengan } \\
\text { menambahkan ilustrasi piala dalam } \\
\text { board. Informasi yang diletakkan di } \\
\text { dalamnya juga berisi cara bermain, } \\
\text { informasi pemenang dan informas } \\
\text { mengenai hadiah yang akan } \\
\text { didapatkan. }\end{array}$ \\
\hline 6 & Main board & $=$ & $\begin{array}{l}\text { Desain mainboard dibagi menjadi } 3 \\
\text { bagian dengan penggunaan warna } \\
\text { dan ilustrasi yang berbeda. Pada } \\
\text { bagian tengah terdapat desain } \\
\text { utama untuk permainan dengan } \\
\text { menggunakan warna kuning } \\
\text { kemudian disebelah kiri terdapat } \\
\text { berita-berita terkini dan sebelah kiri } \\
\text { terdapat informasi mengenai } \\
\text { pengguna. }\end{array}$ \\
\hline
\end{tabular}

Tahap 4. Evaluation Against Requirements

Setelah desain user interface dibuat, evaluasi dilakukan dengan melibatkan pengembang dan calon pengguna yang akan menggunakan game tersebut. Dari evaluasi yang dilakukan terdapat dua poin yang perlu dilakukan untuk memaksimalkan desain game yang ada point pertama ada pada user interface yang perlu disempurnakan dan yang kedua adalah menganimasikan ilustrasi yang ada. Animasi diharapkan dapat menambahkan kesan hidup dalam game yang dibuat.

\section{KESIMPULAN}

Berdasarkan tahapan yang telah dilakukan maka dapat disimpulkan bahwa desain user interface telah dibuat melalui proses yang sesuai dengan spesifikasi yang diharapkan oleh pengguna sehingga menghasilkan desain UI dalam bentuk ilustrasi 2D sehingga desain ilustrasi yang dibuat dapat mengurangi masalah besaran file. Desain yang dibuat diharapkan dapat menambah referensi desain yang ringan untuk game yang serupa.

Penggunaan metode UDC dalam pembuatan user interface yang melibatkan pengguna dan pengembang sangat membantu dalam proses pembuatan User interface yang diharapkan namun perlu penggunaan metode yang berbeda apabila desain yang ada akan diaplikasikan kedalam bentuk prototipe. Pembuatan desain yang telah ada terbatas pada perancangan desain halaman-halaman utama saja, desain mungkin akan dapat ditambah dan dikembangkan apabila game kedepannya lebih berkembang. 


\section{DAFTAR PUSTAKA}

Abras, C., Maloney-Krichmar, D. \& Preece, J. (2004). User-centered design. Bainbridge, W. Encyclopedia of Human-Computer Interaction., 37(4), pp. 445-456.

Deliusno. (2013). 10 Game Facebook Terpopuler di Indonesia. [Online] url: https://tekno.kompas.com/read/2013/07/16/1148114/10.igamei.facebook .terpopuler.di.indonesia. [Accessed 2010 2020].

EDITORS, H. (2017). Video Game History. [Online] url: https://www.history.com/topics/inventions/history-of-video-games. [Accessed 2710 2020].

Lindsay, G. (2005). Game Type and Game Genre. [Online] url: https://www.researchgate.net/publication/262250061_Game_Type_and_ Game_Genre [Accessed 1910 2020].

Mayhew, D. J. (1999). The Usability Engineering Lifecycle: A Practitioner's Handbook for User interface Design (Interactive Technologies). 1st Edition ed. United Stated: Morgan Kaufmann.

Mcleod, R. (1995). Sistem Informasi Management. Jakarta: PT. Prenhalindo.

Olga, R. (2015). Website Redesign: Improving User Experience and User interface on the Havusport Website (Thesis), Finland: University of Applied Science.

Sani, K. (2014). Perceptual Human Computer Interaction / Interface Menggunakan Teknik Computer.

Suteja, B. R. \& Harjoko, A. (2008). Perancangan User interface E-Learning Berbasis Web. Yograkarta, UPN "Veteran" Yogyakarta, pp. 36 - 46 